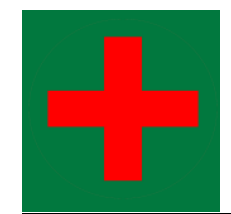

\title{
Penerimaan Pengguna Terhadap Sistem Informasi Manajemen Rekam Medis (SIMRM) Di RSUD Tebet Jakarta Selatan Tahun 2021
}

\author{
Anggi Alpiyani ${ }^{1}$, Nanda Aula Rumana ${ }^{2}$, Daniel Happy Putra ${ }^{3}$, Laela Indawati ${ }^{4}$ \\ 1,2,3,4 Program Studi Rekam Medis dan Informasi Kesehatan, Universitas Esa Unggul, \\ Kota Jakarta Barat, Indonesia \\ Email: ${ }^{1}$ anggi.esaunggul@gmail.com, ${ }^{2}$ nanda.rumana@esaunggul.ac.id
}

\begin{abstract}
Rumah Sakit Umum Daerah Tebet, South Jakarta, has been using a computerized management information system for medical record services called the Hospital Information System (HIS) since 2017. The presence of the Medical Record Management Information System (SIMRM) at the Rumah Sakit Umum Daerah Tebet, has brought many influences to services. Along with the implementation of SIMRM, it is necessary to assess whether the system is running properly and has been accepted by its users, in this case the medical record officer. The research method used The research method that the researcher uses is a quantitative descriptive method using the Technology Acceptance Model (TAM) to assess the perception of technology users as seen from 5 constructs, namely perceived ease of use, perceived usefulness., perceptions of attitudes toward using, behavioral intention to use and actual usage by distributing questionnaires to 16 respondents consisting of 7 medical record unit officers and 9 registration unit officers. The results showed that the average user acceptance of SIMRM in South Jakarta Hospital as seen from the 5 TAM constructs was $75 \%$ received and $25 \%$ did not receive which means SIMRM was received by the user. It is recommended for the hospital to conduct socialization and training in accordance with the needs of officers.
\end{abstract}

Keywords: Acceptend, Medical Record System, Information System, TAM, User Perception

\begin{abstract}
Abstrak
Rumah Sakit Umum Daerah Tebet, Jakarta Selatan, telah menggunakan sistem informasi manajemen terkomputerisasi untuk pelayanan rekam medis yang disebut Sistem Informasi Rumah Sakit (HIS) sejak tahun 2017. Kehadiran Sistem Informasi Manajemen Rekam Medis (SIMRM) di Rumah Sakit Umum Daerah Tebet, telah membawa banyak pengaruh terhadap pelayanan. Seiring dengan penerapan SIMRM, perlu dilakukan penilaian apakah sistem sudah berjalan dengan baik dan sudah diterima oleh penggunanya, dalam hal ini petugas rekam medis. Metode penelitian yang digunakan peneliti adalah metode deskriptif kuantitatif dengan menggunakan Technology Acceptance Model (TAM) untuk menilai persepsi pengguna teknologi dilihat dari 5 konstruk yaitu persepsi kemudahan ,persepsi kegunaan, persepsi sikap penggunaan, niat perilaku penggunaan dan penggunaan aktual dengan menyebarkan kuesioner kepada 16 responden yang terdiri dari 7 petugas unit rekam medis dan 9 petugas unit registrasi. Hasil penelitian menunjukkan bahwa rata-rata penerimaan
\end{abstract}


pengguna SIMRM di RS Jakarta Selatan dilihat dari 5 konstruk TAM adalah $75 \%$ diterima dan 25\% tidak menerima yang berarti SIMRM diterima dengan baik oleh pengguna. Disarankan kepada pihak rumah sakit untuk melakukan sosialisasi dan pelatihan sesuai dengan kebutuhan petugas.

Kata Kunci : Penerimaan, Rekam Medis Sistem, Informasi Sistem, Persepsi Pengguna

\section{PENDAHULUAN}

Kemajuan teknologi informasi mengharuskan sarana pelayanan kesehatan penghasil data atau informasi senantiasa memperhatikan masukan yang diberikan oleh tenaga kesehatan (Hatta, 2012). Salah satu perkembangan teknologi informasi dibidang kesehatan adalah Sistem Informasi Manajemen Rumah Sakit (SIMRS) yang wajib diterapkan di rumah sakit (Kemenkes RI, 2013) .

Sistem Informasi Manajemen Rekam Medis (SIMRM) merupakan subsistem dari Sistem Informasi Manajemen Rumah Sakit (SIMRS) secara keseluruhan yang memiliki peran sangat penting dalam meningkatkan mutu dan pelayanan di rumah sakit itu sendiri (Silfani \& Achadi, 2014). Oleh karena itu perlu adanya teknologi informasi yang mendukung petugas rekam medis yaitu SIMRM dalam melakukan pelayanan di rumah sakit, tetapi dengan adanya teknologi baru petugas rekam medis harus mempelajari kembali cara penggunaan yang berbeda jauh dengan sistem rekam medis yang dilakukan secara manual (Rachmani, 2017).

Maka dari itu agar dapat mengetahui tingkat penerimaan SIMRM perlu diadakan evaluasi dengan menggunakan salah satu teknologi penelitian yang mengkaji faktor penerimaan pengguna terhadap teknologi komputer yaitu Technology Acceptance Model (TAM). Tingkat penerimaan pengguna dalam model TAM ditentukan oleh 5 konstruksi, yaitu: persepsi pengguna terhadap kemudahan (perceived ease of use), persepsi pengguna terhadap kemanfaatan (perceived usefulness), sikap dalam menggunakan (attitude toward using), perhatian untuk menggunakan (behavioral intention to use), dan pemakaian nyata (actual usage) (Davis, 1989).

Diketahui pada salah satu penelitian sebelumnya yang dilakukan menggunakan teknologi TAM pada SIMRM di PKU Muhammadiyah Karang Anyar didapatkan bahwa penerimaan pengguna terhadap SIMRM sebesar 90,13\% dan pengguna yang tidak menerima sebesar 9,87\% (Nurhayati, Arif, \& Hidayah, 2019). Penelitian tersebut didapatkan kesimpulan bahwa penerimaan SIMRM belum sepenuhnya di terima oleh pengguna sistem tersebut yang dilihat dari 5 kontruksi teknologi TAM.

RSUD Tebet Jakarta Selatan salah satu rumah sakit menggunakan SIMRM yang dinamakan Hospital Information System (HIS) sejak tahun 2017 dalam palayanannya dengan total 16 petugas pada unit rekam medis dan pendaftaran . Pada saat pengimplementasian HIS pada unit rekam medis RSUD Tebet Jakarta Selatan mengalami beberapa kendala yaitu, sistem tidak berjalan sesuai perintah sehingga mengalami double atau hilang pada pendataan dan kurangnya kemampuan pengguna (user) karena kurangnya pelatihan atau orientasi pada penggunaan HIS yang akan mengakibatkan terhambatnya proses pelayanan kesehatan, karena proses penginputan 
data yang memang sebelumnya dilakukan secara manual. Pada permasalahan diatas peneliti ingin mengetahui bagaimana penerimaan pengguna terhadap SIMRM adapun tujuan dari penelitian ini adalah ingin mengetahui penerimaan pengguna terhadap SIMRM di RSUD Tebet Jakarta Selatan Tahun 2021.

\section{METODE}

Metode penelitian yang peneliti gunakan yaitu metode deskriptif yang bersifat kuantitatif. Populasi dalam penelitian ini yaitu seluruh pengguna SIMRM di RSUD Tebet Jakarta Selatan tahun 2021. Sampel yang digunakan dalam penelitian ini yaitu seluruh populasi yang berjumlah 16 responden yang terdiri atas 7 petugas unit rekam medis dan 9 petugas bagian pendataran rawat jalan dan rawat inap. Cara pengambilan sampel secara non random dengan teknik sampel jenuh dimana semua populasi dijadikan sampel. Teknik pengumpulan data yang digunakan dalam penelitian ini adalah pengguna diminta untuk mengisi langsung didalam angket dengan instrumen menggunakan angket yang diberikan secara langsung dan tertulis kepada seluruh petugas yang menggunakan SIMRM di Rumah Sakit Umum Derah Tebet.

\section{HASIL}

Gambaran Penerimaan Pengguna Sistem Informansi Manajemen Rekam Medis RSUD Tebet Jakarta Selatan Melalu 5 Dimensi Konstruk Technology Acceptance Model (TAM)

Tabel 1. penilaian pengguna terhadap SIMRM melalui 5 Dimensi Konstruk Technology Acceptance Model (TAM)

\begin{tabular}{|c|c|c|c|c|c|}
\hline No. & Pernyataan & & Setuju & & \\
\hline & Persepsi Kegunaan (Perceived Ease Of Use) & $\mathrm{N}$ & $\%$ & $\mathrm{~N}$ & $\%$ \\
\hline 1 & $\begin{array}{l}\text { Menggunakan SIMRM memberikan hasil yang } \\
\text { akurat pada data }\end{array}$ & 13 & $\begin{array}{l}81,30 \\
\%\end{array}$ & 3 & $18,8 \%$ \\
\hline 2 & $\begin{array}{l}\text { Menggunakan SIMRM meningkatkan evektivitas } \\
\text { saya dalam bekerja }\end{array}$ & 16 & $100 \%$ & 0 & $0 \%$ \\
\hline 3 & $\begin{array}{l}\begin{array}{l}\text { Menggunakan } \\
\text { pekerjaan }\end{array} \\
\text { SIMRM }\end{array}$ & 14 & $87,5 \%$ & 2 & $12,5 \%$ \\
\hline 4 & $\begin{array}{l}\text { Menggunakan SIMRM dalam pekerjaan } \\
\text { memungkinkan menyelesaikan tugas lebih cepat }\end{array}$ & 16 & $100 \%$ & 0 & $0 \%$ \\
\hline 5 & $\begin{array}{l}\text { Menggunakan SIMRM meningkatkan produktivitas } \\
\text { petugas rekam medis }\end{array}$ & 11 & $68,8 \%$ & 5 & $31,3 \%$ \\
\hline 6 & $\begin{array}{l}\text { Secara keseluruhan penggunaan SIMRM sangat } \\
\text { berguna }\end{array}$ & 15 & $93,8 \%$ & 1 & $6,8 \%$ \\
\hline & Persepsi Kemudahan (Perceived Usefulness) & & & & \\
\hline 1 & Penggunaan SIMRM mudah di akses dan di pelajari & 14 & $87,5 \%$ & 2 & $12,5 \%$ \\
\hline 2 & Bahasa SIMRM mudah di pahami & 16 & $100 \%$ & 0 & $0 \%$ \\
\hline 3 & Tersedianya petunjuk atau modul penggunaan & 14 & $87,5 \%$ & 2 & $12,5 \%$ \\
\hline
\end{tabular}


SIMRM

\begin{tabular}{llllll}
\hline 4 & Petunjuk atau modul SIMRM sangat memudahkan & 14 & $87,5 \%$ & 2 & $12,5 \%$ \\
\hline & $\begin{array}{l}\text { Sikap Menggunakan SIMRM (Attitude Toward } \\
\text { Using) }\end{array}$ & & & \\
\hline 1 & Senang dalam menggunakan SIMRM & 16 & $100 \%$ & 0 & $0 \%$ \\
\hline 2 & Mempelajari penggunaan SIMRM & 15 & $93,8 \%$ & 1 & $6,3 \%$ \\
\hline 3 & Bosan dalam penggunaan SIMRM & 0 & $0 \%$ & 16 & $100 \%$ \\
\hline 4 & $\begin{array}{l}\text { Secara keseluruhan tidak suka dan merasa kesulitan } \\
\text { dalam mengakses SIMRM }\end{array}$ & $0 \%$ & 16 & $100 \%$ \\
\hline & $\begin{array}{l}\text { Niat Perilaku Dalam Menggunakan (Behavioral } \\
\text { Intention) }\end{array}$ & & & & \\
\hline 1 & $\begin{array}{l}\text { Masih ingin terus menggunakan SIMRM dala } \\
\text { pekerjaan }\end{array}$ & 15 & $93,8 \%$ & 1 & $6,3 \%$ \\
\hline 2 & Percaya penggunaan SIMRM dapat memudahkan & 16 & $100 \%$ & 0 & $0 \%$ \\
\hline 3 & $\begin{array}{l}\text { Niat dalam menyelesaikan pekerjaan semakin } \\
\text { bertambah }\end{array}$ & $87,5 \%$ & 2 & $12,5 \%$ \\
\hline 4 & $\begin{array}{l}\text { Saya memberi masukan terhadap penggunaan } \\
\text { SIMRM dalam pengoprasiannya }\end{array}$ & $87,5 \%$ & 2 & $12,5 \%$ \\
\hline & $\begin{array}{l}\text { Penggunaan SIMRM Sesungguhnya (Actual } \\
\text { Usage) }\end{array}$ & & & & \\
\hline 1 & $\begin{array}{l}\text { Saya merasa jujur dalam mengisi data pasien pada } \\
\text { SIMRM }\end{array}$ & 16 & $100 \%$ & 0 & $0 \%$ \\
\hline 2 & $\begin{array}{l}\text { Penggunaan SIMRM sesuai dengan prosedur dan } \\
\text { modul }\end{array}$ & 16 & $100 \%$ & 0 & $0 \%$ \\
\hline 3 & $\begin{array}{l}\text { Saya menerima penggunaan SIMRM dalam } \\
\text { pekerjaan saya }\end{array}$ & 16 & $100 \%$ & 0 & $0 \%$ \\
\hline 4 & $\begin{array}{l}\text { Saya merasa nyaman menggunakan SIMRM dalam } \\
\text { pekerjaan }\end{array}$ & 16 & $100 \%$ & 0 & $0 \%$ \\
\hline 5 & $\begin{array}{l}\text { Saya memahami cara penggunaan SIMRM yang } \\
\text { baik dan benar }\end{array}$ & 16 & $100 \%$ & 0 & $0 \%$ \\
\hline 6 & $\begin{array}{l}\text { Penggunaan SIMRM sangant bermanfaat bagi } \\
\text { pekerjaan saya }\end{array}$ & 16 & $100 \%$ & 0 & $0 \%$ \\
\hline
\end{tabular}

Berdasarkan tabel 1 diatas dapat diketahui pada konstruk kegunaan (perceived ease of use), bahwa terdapat 5 responden $(31,3 \%)$ menyatakan kegunaan SIMRM tidak meningkatkan produktivitas petugas. Pada persepsi kemudahan (Perceived Usefulness), bahwa terdapat 2 responden (12,5\%) menyatakan penggunaan SIMRM sulit dipelajari dan tidak tersedianya petunjuk atau modul, yang berarti penggunaan SIMRM kurang memudahkan petugas dalam melakukan pekerjaan. Pada persepsi sikap menggunakan (Attitude Toward Using), bahwa terdapat 1 responden $(6,3 \%)$ menyatakan pengguna SIMRM menyatakan tidak akan mempelajari penggunaan SIMRM, yang berarti pengguna SIMRM enggan mempelajari penggunaan SIMRM dengan baik dan benar. Pada persepsi niat perilaku SIMRM ( Behavioral Intention), bahwa terdapat 2 responden $(12,5 \%)$ menyatakan pengguna SIMRM menyatakan tidak memberikan masukan terhadap penggunaan SIMRM, yang berarti pengguna SIMRM enggan memberi masukan terhadap penggunaan SIMRM. Pada persepsi penggunaan SIMRM sesungguhnya (Actual Usage),bahwa 16 responden menunjukkan hasil presentase 
positif seluruhnya sebesar (100\%), yaitu pengguna SIMRM merasa jujur dan nyaman, penggunaan sudah sesuai prosedur, dan sangat bermanfaat dalam pekerjaan.

Tabel 2. Hasil persentase pada masing masing penerimaan SIMRM melalui 5 konstruk TAM

\begin{tabular}{lcc}
\hline Kegunaan (Perceived Ease Of Use) & Jumlah & Presentase \\
\hline Tinggi & 15 & $93,8 \%$ \\
\hline Rendah & 1 & $6,3 \%$ \\
\hline Kemudahan (Perceived Usefulness) & & \\
\hline Tinggi & 14 & $87,5 \%$ \\
\hline Rendah & 2 & $12,5 \%$ \\
\hline
\end{tabular}

Sikap Menggunakan (Attitude Toward Using)

\begin{tabular}{lcc}
\hline Tinggi & 13 & $81,3 \%$ \\
\hline Rendah & 3 & $18,8 \%$ \\
\hline $\begin{array}{l}\text { Niat Perilaku dalam Menggunakan (Behavioral } \\
\text { Intention) }\end{array}$ & & \\
\hline Tinggi & 14 & $87,5 \%$ \\
\hline Rendah & 2 & $12,5 \%$ \\
\hline Penggunaan Sesungguhnya (Actual Usage) & & \\
\hline Tinggi & 16 & $100 \%$ \\
\hline Rendah & 0 & $0 \%$ \\
\hline Total & 16 & $100 \%$ \\
\hline
\end{tabular}

Berdasarkan tabel 2 diatas dapat diketahui bahwa pada kosntruk kegunaan (Perceived Ease Of Use) bahwa 15 responden memberikan penilaian tinggi terhadap kegunaan yang di rasakan dengan presentase 93,8\% dengan 1 responden memberikan nilai rendah sebesar 6,3\%. Pada konstruk Kemudahan (Perceived Usefulness) bahwa 14 responden memberikan penilaian tinggi terhadap kemudahan yang dirasakan dengan presentase 85,5\% dengan 2 responden memberikan nilai rendah sebesar $12,5 \%$. Pada konstruk Sikap Menggunakan (Attitude Toward Using) bahwa 13 responden memberikan penilaian tinggi terhadap sikap menggunakan dengan presentase $81,3 \%$ dan 3 responden memberikan nilai rendah dengan presentase 13,8\%. Pada konstruk Niat Perilaku dalam Menggunakan (Behavioral Intention) bahwa 14 responden memberikan penilaian tinggu terhadap niat perilaku dalam menggunakan sebesar 87,5\% dan 2 responden yang memberikan nilai rendah sebesar 12,5\%. Pada konstruk Penggunaan Sesungguhnya (Actual Usage) bahwa 16 responden memberikan nilai tinggi terhadap penggunaan sesungguhnya dengan presentase $100 \%$ dan tidak da responden yang memberikan penilaian rendah terhapa konstruk penggunaan sesungguhnya.

Tabel 3. Hasil penerimaan pengguna terhadap SIMRM di RSUD Tebet Jakarta Selatan terhadap 5 konstruk TAM 


\begin{tabular}{ccc}
\hline Menerima & 12 & $75 \%$ \\
\hline Tidak Menerima & 4 & $25 \%$ \\
\hline Total & 16 & $100 \%$ \\
\hline
\end{tabular}

Berdasarkan tabel 3 dapat diketahui bahwa nilai akhir penerimaan pengguna terhadap SIMRM di RSUD Tebet Jakarta Selatan yang di lihat melalui 5 kontruk TAM. yaitu $75 \%$ diterima oleh pengguna dan $25 \%$ tidak menerima oleh pengguna. Hal ini mennjukan bahwa penggunaan SIMRM di RSUD Tebet Jakarta Selatan sudah cukup di terima oleh pengguna.

\section{PEMBAHASAN}

\section{Gambaran Penerimaan Pengguna Sistem Informansi Manajemen Rekam Medis RSUD Tebet Jakarta Selatan Melalu 5 Dimensi Konstruk Technology Acceptance Model (TAM)}

\section{Presepsi Kegunaan (Perceived Ease Of Use)}

Hasil penelitian yang dilihat dari presepsi kegunaan (perceived ease of use) diperoleh dari 15 responden menunjukkan nilai presentase positif sebesar 93,8\% memiliki kriteria sangat tinggi. hasil ini menujukan bahwa kegunaan dari SIMRM di RSUD Tebet Jakarta Selatan sangat berguna dan memudahkan dalam pekerjaan. Dan 1 responden menunjukkan nilai presentase negatif sebesar 6,3\% yang berarti masih ada pengguna SIMRM di RSUD Tebet Jakarta Selatan tidak mendapat kegunaan dari SIMRM dalam pekerjaan. Hasil ini mendukung teori Theori of Reasoned Action (TRA) membuktikan bahwa variabel kemudahan penggunaan, dalam studinya apakah penerimaan penggunaan mikro komputer dipengaruhi oleh kemudahan penggunaan yang diharapkan oleh si pengguna atau karena tekanan sosial. Teknologi informasi digunakan bukan mutlak karena adanya tekanan sosial, sehingga dapat simpulkan bahwa penggunaan teknologi informasi bukan karena adanya unsur tekanan, tetapi karena memang mudah digunakan (Supriyanti \& Cholil, 2017).

\section{Persepsi Kemudahan (Perceived Usefulness)}

Hasil penelitian yang dilihat dari persepsi kemudahan (Perceived Usefulness) diperoleh dari 14 responden menunjukkan nilai presentase positif sebesar 85,5\% memiliki kriteria sangat tinggi. hasil ini menujukan bahwa kemudahan dari SIMRM di RSUD Tebet Jakarta Selatan sangat memudahkan dalam pekerjaan. Dan 2 responden menunjukan nilai presentase negatif sebesar $12,5 \%$ yang berarti masih ada pengguna SIMRM di RSUD Tebet Jakarta Selatan tidak mendapat kemudahan dari SIMRM dalam pekerjaan. Hasil ini mendukung teori David (1989) bahwa Persepsi Kemudahan (Perceived Usefulness) diartikan sebagai tingkatan bagaimna seseorang mempercayai kemudahan sistem tertentu dapat meningkatkan prosuduktivitasn dan kinerja pengguna. Menurut david (1989) mendefiniskan Persepsi Kemkudahan (Perceived Usefulness) sebagai suatu tingkatan dimana seseorang percaya bahwa penggunaan yang mudah dapat meningkatkan prestasi kerja orang tersebut (Supriyanti \& Cholil, 2017). 


\section{Persepsi Sikap Menggunakan (Attitude Toward Using)}

Hasil penelitian yang dilihat dari persepsi sikap menggunakan (Attitude Toward Using) diperoleh dari 13 responden menunjukkan nilai presentase positif sebesar 81,3\% memiliki kriteria sangat tinggi. hasil ini menujukan bahwa sikap pengguna dari SIMRM di RSUD Tebet Jakarta Selatan sangat puas dan memudahkan dalam pekerjaan. Dan 3 responden menunjukkan nilai presentase negatif sebesar 18,8\% yang berarti masih ada pengguna SIMRM di RSUD Tebet Jakarta Selatan tidak puas dalam menggunakan SIMRM dalam pekerjaan. Hal ini mendukung teori Davis (1989) bahwa kecenderungan seseorang dalam menggunakan suatu teknologi dilohat dari minat pengguna tersebut untuk tetap menggunakan sistem teknologi tersebut.Sikap menggunakan (attitude toward using) di artikan bahwa " a person's performance of specific behaviour", artinya kinerja seseorang dari perilaku tertentu. Yang di artikan bahwa seseorang akan puas menggunakan sistem jika mereka meyakini bahwa sistem tersebut mudah digunakan dapat meningkatlan kerja produktivitas mereka yang tercermin dari kondisi nyata penggunaan (Davis, 1989).

\section{Persepsi Niat Perilaku Pengguna (Behavioral Intention)}

Hasil penelitian yang dilihat dari persepsi niat perilaku pengguna SIMRM (Behavioral Intention) diperoleh dari 14 responden menunjukan nilai presentase positif sebesar 87,5\% memiliki kriteria sangat tinggi. hasil ini menujukan bahwa niat pengguna dari SIMRM di RSUD Tebet Jakarta Selatan sangat baik dan memudahkan dalam pekerjaan. Dan 3 responden menunjukkan nilai presentase negatif sebesar 18,8\% yang berarti masih ada pengguna SIMRM di RSUD Tebet Jakarta Selatan tidak senang dalam menggunakan SIMRM dalam pekerjaan. Dapat disimpulkan bahwa niat perilaku (Behavioral Intention) yang merupakan kecenderungan niat perilaku untuk tetap menggunakan teknologi sistem yang di gunakan. Yang di artikan bahwa jika seseorang merasa niat dan termotivasi maka mereka meyakini bahwa sistem yang mereka gunakan dalam pekerjaan mampu membuat pengguna masih ingin terus menggunakan sistem masa depan n (Abramson,J., Dawson, 2015).

\section{Persepsi Penggunaan Sesungguhnya (Actual Usage)}

Hasil penelitian dari persepsi penggunaan sesungguhnya (Actual Usage) diperoleh dari 16 responden menunjukkan nilai presentase positif sebesar $100 \%$ memiliki kriteria sangat tinggi dan sempurna . hasil ini menujukan bahwa sikap penggunaan dari SIMRM di RSUD Tebet Jakarta Selatan sangat baik dan mampu membantu pengguna menyelesaikan pekerjaannya tepat. Berdasarkan uraian tersebut menunjukkan bahwa sebagian besar pengguna setuju dan meyakini bahwa sistem tersebut mudah digunakan dan meningkatkan produktivitas pengguna yang tercermin dari kondisi nyata penggunaan sistem tersebut. Hal ini sesuai dengan Theory of Reasoned Action (TRA) dalam Supriyati menyatakan bahwa actual usage adalah kondisi nyata penggunaan sistem. Dikonsepkan dalam bentuk pengukuran terhadap frekuensi dan durasi waktu penggunaan teknologi. Seseorang akan puas menggunakan sistem jika mereka meyakini bahwa sistem tersebut mudah digunakan dan akan meningkatkan produktifitas mereka yang tercermin dari kondisi nyata penggunaan (Supriyanti \& Cholil, 2017). 


\section{Hasil penerimaan pengguna terhadap SIMRM di RSUD Tebet Jakarta Selatan terhadap 5 konstruk TAM}

Berdasarkan penelitian penerimaan pengguna terhadap SIMRM di RSUD Tebet Jakarta Selatan dengan menggunakan 5 konstruk TAM yaitu Persepsi kegunaan (perceived usefulness),Persepsi kemudahan (perceived ease of use), Sikap menggunakan (attitude toward using) ,Niat perilaku menggunakan (behavioral intention to use), Penggunaan teknologi sesungguhnya (actual use). Dengan nilai persepsi paling tinggi yaitu, penggunaan sesungguhnya (actual usage) dengan hasil persentase sebesar 100\% dan nilai persepsi paling rendah yaitu, sikap menggunakan (attitude toward using) dengan hasil presentase sebesar 81,3\%. Maka dapat di simpulkan bahwa presentase penerimaan pengguna terhadap SIMRM di RSUD Tebet Jakarta Selatan sebesar 75\% dengan kualifikasi $25 \%$ tidak menerima dan $75 \%$ menerima. Hal ini menunjukan bahwa penggunaan SIMRM dalam pekerjaan diterima oleh pengguna.

\section{KESIMPULAN DAN SARAN}

Gambaran penerimaan pengguna terhadap SIMRM di RSUD Tebet Jakarta Selatan di lihat dari persepsi kegunaan menyatakan bahwa 15 pengguna $(93,8 \%)$ memberikan penilaian tinggi dan 1 pengguna $(6,3 \%)$ memberikan penilaian rendah dalam penggunaan SIMRM. Gambaran penerimaan pengguna terhadap SIMRM di RSUD Tebet Jakarta Selatan di lihat dari persepsi kemudahan menyatakan bahwa 14 pengguna $(85,5 \%)$ memberikan penilain tinggi dan 2 pengguna $(12,5 \%)$ memberikan penilaian rendah dalam kemudahan menggunakan SIMRM. Gambaran penerimaan pengguna terhadap SIMRM di RSUD Tebet Jakarta Selatan di lihat dari persepsi sikap menggunakan menyatakan bahwa 13 pengguna $(81,3 \%)$ memberikan penilaian tinggi dan 3 pengguna $(18,8 \%)$ memberikan penilain rendah dalam penggunaan SIMRM. Gambaran penerimaan pengguna terhadap SIMRM di RSUD Tebet Jakarta Selatan di lihat dari persepsi niat perilaku menyatakan bahwa 14 pengguna $(85,5 \%)$ memberikan penilaian tinggi dan 2 pengguna (12,5\%) memberikan penilaian rendah dalam penggunaan SIMRM. Gambaran penerimaan pengguna terhadap SIMRM di RSUD Tebet Jakarta Selatan di lihat dari persepsi penggunaan sesungguhnya menyatakan bahwa 16 pengguna (100\%) menggunakan SIMRM. Diartikan bahwa seluruh pengguna menggunakan SIMRM dalam pekerjaannya. Gambaran penerimaan pengguna terhadap SIMRM di RSUD Tebet Jakarta Selatan di lihat dari 5 konstruk TAM dapat disimpulkan 12 pengguna (75\%) menerima dan 4 pengguna $(25 \%)$ tidak menerima SIMRM dalam pekerjaanya.

Saran dari peneliti untuk pengguna SIMRM di RSUD Tebet Jakarta Selatan adalah Peningkatan sosialisasi dan pelatihan sesuai dengan kebutuhan petugas untuk meningkatkan kesadaran akan manfaat dan keterampilan pengguna dalam penggunaan SIMRM. Sosialisasi dan evaluasi kepada seluruh petugas tentang penggunan SIMRM supaya tercapai maksimaln penggunaan teknologi informasinya serta menumbuhkan niat kepada kepada seluruh karyawan untuk menggunakan SIMRM secara terus menenerus di waktu yang akan datang, sehingga kedepannya sikap petugas akan terus menggunakan SIMRM dan peningkatkan kerjasama antara pengguna SIMRM dengan rekanan IT dalam tahap perancangan, uji coba, implementasi, dan pengembangan sistem 
sehingga pengguna merasa berperan dalam sukses dan gagalnya sistem. Hal ini di harapkan dapat mengurangi presepsi negatif terhadap SIMRM.

\section{DAFTAR PUSTAKA}

Abramson, J., Dawson M and S. An Examination of the Prior Use of ELearning Within an Extended Technology Acceptance Model and the Factors that Influence the Behaviorar Intention of Users to Use M-Learning. Published online 2015:1-9.

Davis FD. Perceived usefulness, perceived ease of use, and user acceptance of information technology. MIS Q 1989

Hatta GR (2012). Pedoman Manajemen Informasi Kesehatan di Sarana Pelayanan Kesehatan: Revisi Buku Petunjuk Teknis Penyelenggaraan Rekam Medis. Med Rec Rumah Sakit dan Pedoman Pengelolaan Rekam Medis Rumah Sakit di Indones (1994, 1997), edk, 2. 2012;2.

Kemenkes RI. Peraturan menteri kesehatan RI nomor 82 tentang sistem manajeman rumah sakit. 2013;(87):1-36.

Nurhayati, Arif YWT, Hidayah IN. Analisis Tingkat Penerimaan Pengguna Terhadap Teknologi Sistem Informasi Rekam Medis Di PKU Muhammadiyah Karanganyar. Pros Call Pap SMIKNAS. Published online 2019:258-268. https://ojs.udb.ac.id/index.php/smiknas/article/view/694.

Silfani WE, Achadi A, Sakit MR, Masyarakat K, Indonesia U. Di Rs Omni Medical Center Tahun 2014. Published online 2014.

Supriyanti S, Cholil M. Aplikasi Technology Acceptance Model Pada Sistem Informasi Manajemen Rumah Sakit Di Rumah Sakit Ortopedi Prof. Dr. R. Soeharso Surakarta.J Manaj Dayasaing. 2017;18(1):42. doi:10.23917/dayasaing.v18i1.3817. 